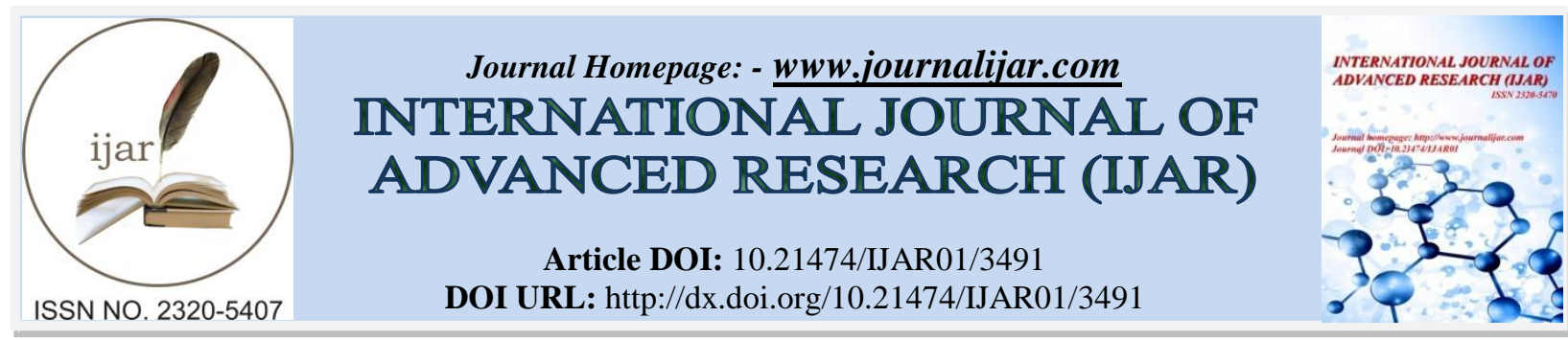

RESEARCH ARTICLE

\title{
EVALUATION OF T- REGULATORY CELLS IN BREAST CANCER.
}

Ola Sayed Mohamed Ali ${ }^{1}$, Maha A. El-Taweel ${ }^{2}$, Iman Attia Abdel El-Gawad ${ }^{2}$ and Eman Ahmed Gouda ${ }^{3}$.

1. Professor of Biochemistry, Faculty of Pharmacy for girls, Al-Azhar University.

2. Associate professor of clinical pathology, National Cancer Institute, Cairo University.

3. B.Sc. of pharmaceutical sciences, Faculty of Pharmacy, Cairo University.

\section{Manuscript Info}

Manuscript History

Received: 11 January 2017

Final Accepted: 12 February 2017

Published: March 2017

Key Words: -

CD4+CD25+, T regulatory cells, Breast cancer

\begin{abstract}
Treg cells have an important role in cancer, enabling tumors to elude host anti-tumor immune response. CD4+CD25+ Treg cells constitute 5$10 \%$ of peripheral blood CD4+ lymphocytes. Also, CD8+CD25+ cells have been shown a suppressive effect and share phenotypic and functional features with CD4+CD25+ Treg cells.

Aim of the work: This work was done to evaluate the frequency of expression of different Treg cells in the peripheral blood of breast cancer patients and to elucidate their impact on clinical and laboratory parameters.

Patients and Methods: This study included forty-seven Egyptian breast cancer patients (30 de novo patients and 17 after surgery patients) and 13 healthy controls and 18 benign breast patients. They were tested by Flow Cytometry

Results:CD4+CD25+ Treg cells were significantly higher in the de novo compared to the healthy controls and in the after-surgery group compared to the healthy controls and benign breast groups $(\mathrm{P}<\mathbf{0 . 0 0 0 1})$, while CD4+CD25hi were significantly higher in both de novo and after surgery patients as compared to healthy controls $(\mathrm{P}<0.0001)$. Conclusion: some Treg cells as CD4+CD25+ cells are predominant in breast cancer patients.
\end{abstract}

Copy Right, IJAR, 2017, All rights reserved.

\section{Introduction: -}

Breast cancer is the most frequently diagnosed cancer and the leading cause of cancer deaths among females worldwide, accounting for $23 \%$ of the total new cancer cases and 14\% of the total cancer deaths in 2008(Jamal et al. 2011). Breast cancer patients have immune system functional deviations, that affect immune cells that infiltrate the tumor, but also cells from the blood compartment, even in the absence of a metastatic disease (Pinho et al., 2016). Regulatory T-cells (Treg cells) are a variety of cells that display the capacity to suppress T-cell proliferation in vitro and prevent immune pathology in vivo Treg cells have an important role in cancer, enabling tumors to elude host anti-tumor immune response (Maggiet al., 2005).

CD4+CD25+ Treg cells constitute 5-10\% of peripheral blood CD4+ lymphocytes (Maggiet al., 2005). They express CD25 (the alpha chain of the IL-2 receptor), cytotoxic $\mathrm{T}$ lymphocyte-associatedantigen-4 (CTLA-4), a glucocorticoid induced TNFareceptor (GITR), and a novel member of the fork head transcription factors (Foxp3) (Zhang et al., 2007). 
CD8+CD25+ cells have been recently shown a suppressive effect. CD8+CD25+Treg cells share phenotypic and functional features with CD4+CD25+ Treg cells (Cosmi et al., 2003).

The aim of this study is to evaluate the frequency of expression of different Treg cells in the peripheral blood of Egyptian breast cancer patients and compare their expression with healthy controls and benign breast patients. In addition, to study the relationship between different Treg cells and clinical and laboratory findings and response to treatment in such patients.

\section{Patients and Methods: -}

Forty-seven breast cancer patients, 30 de novo patients (before surgery) and 17 after surgery patients, 13 benign breast disease patients, and 18 apparently healthy volunteering females as a control group were included in this study. The patients were presented to the outpatient's clinic at the National Cancer Institute (NCI), Cairo University over a period of consecutive 11 months. Malignancy was confirmed by histopathological examination. Written informed consent was obtained before enrollment into the study according to ethical committee. Investigations performed included routine hematological and biochemical investigations, and CEA and CA15.3 evaluations.

\section{Methods: -}

Flow cytometric analysis of Treg cells: -

Isolation of mononuclear cells and cell culture: -

Three to four $\mathrm{ml}$ of heparinized blood from each sample was added to $15 \mathrm{ml}$ centrifuge tube and diluted 1:1 with sterile PBS without Magnesium or Calcium salts (Biowest, France catalog no: L0615) under sterile conditions. Ficoll-Hypaque media of density $1.077 \mathrm{gm} / \mathrm{ml}$ (Lymphosep, Lymphozyte Separation Media- Biowest, France Catalog no: L0560) was used to separate the PBMCs. The mononuclear cells were washed and re-suspended under sterile conditions in $3 \mathrm{ml}$ RPMI 1640 with L-Glutamine medium (Biowest, France catalog no: L050) containing 10\% Fetal Bovine Serum (Biowest, South America catalog no: S1810) and $2 \%$ Antibiotic-Antimycotic 100x (Biowest, France catalog no: L0010) which contains Penicillin G, Streptomycin Sulfate \& Amphotericin B.Two $\mathrm{ng} / \mathrm{ml}$ IL2 (Sigma, catalog no: 151342 ) were added for T cell activation. The cells were incubated at $37^{\circ} \mathrm{C}, 5 \% \mathrm{CO}_{2}$ for 48 hours.

Monoclonal Antibodies: -

Fluorescent labeled mouse monoclonal antibodies anti-Human CD4-FITC (Catalog no: F0766, Clone MT310), CD8-PE (Catalog no: R0806, Clone DK25), CD25-FITC (Catalog no: F0801, Clone ACT-1), CD25-PE (Catalog no: R0811, Clone ACT-1) and CD3-RPE-Cy5 (Catalog no: C7067, Clone UCHT1) were obtained from DakoCytomation, Denmark.

\section{Flowcytometric analysis: -}

CD4+CD25+ Treg cells were studied with triple staining of anti-CD4 FITC, anti-CD25 PE and anti-CD3 RPE-Cy5, and CD8+CD25+ Treg cells were studied withanti-CD25 FITC, anti-CD8 PE and anti-CD3 RPE-Cy5 using COULTER ${ }^{\circledR}$ EPICS ${ }^{\circledR}$ XL $^{\text {TM }}$ Flow Cytometer instrument. To determine the percentage of CD4+Treg cells, lymphocytes were gated by plotting forward versus side scatter followed by gating on CD3+CD4+ T cells. These cells were then analyzed for $\mathrm{CD} 25$ expression; $\mathrm{CD} 4+\mathrm{CD} 25 \mathrm{hi}$ were also identified as a tail from the major population of CD4+CD25 cells (Baumgartner and McCarter, 2009).CD8+ Treg cells were detected as percentage of $\mathrm{CD} 8+\mathrm{CD} 25+$ population gated from CD3+ lymphocytes (Fig 1).

\section{Statistical analysis: -}

Data management and analysis were performed using the Statistical Analysis System (SPSS) version 17 software. Comparison of groups with respect to numerical variables was done using the Mann-Whitney test. The Kruskal Wallis test was used to compare medians of 3 or more independent groups. Spearman's rank correlation was used to measure the strength of association between 2 numerical variables. All p-values were two sided, P-values $\leq 0.05$ were considered significant.

\section{Results: -}

Characteristics of the de novo, after surgery \& benign patients' groups are shown in (Table 1.a \& 1.b). CD4+ lymphocytes \% were higher in normal controls and de novo patients compared to the after-surgery patients $(\mathrm{P}=0.04)$ (Table 2). 
CD4+CD25+ Treg cells were significantly higher in the de novo compared to the healthy controls and in the aftersurgery group compared to the healthy controls and benign breast groups $(\mathrm{P}<\mathbf{0 . 0 0 0 1})$, while CD4+CD25hi were significantly higher in both de novo and after surgery patients as compared to healthy controls $(\mathrm{P}<0.0001)($ Table 2$)$.

A significant positive correlation was detected between CD4+CD25+ and CD4+CD25hi Treg cells in both de novo and benign patients' groups, while a significant negative correlation was detected between CD4+CD25and CD8+CD25+ Treg cells in the after-surgery group (Table 3).

CD4+CD25+ Treg cells showed significant negative correlation with age in both de novo and after surgery groups ( $\mathrm{P}=0.038, \mathrm{r}=-0.388 \& \mathrm{P}=0.012, \mathrm{r}=-0.612$ respectively), and significant positive correlation with $\mathrm{CEA}$ in the benign group $(\mathrm{P}=0.005, \mathrm{r}=0.722)$. $\mathrm{CD} 8+\mathrm{CD} 25+$ Treg cells showed significant positive correlation with age in the aftersurgery group $(\mathrm{P}=0.048, \mathrm{r}=0.487)$ (Table 4$)$.

CD4+CD25+ and CD4+CD25hi Treg cells were higher in premenopausal compared to postmenopausal de novo breast cancer patients $(\mathrm{P}=0.017$ and 0.051 respectively). $\mathrm{CD} 4+\mathrm{CD} 25 \mathrm{hi}$ Treg cells were significantly higher in the non-metastatic compared to the metastatic patients in the de novo group $(\mathrm{P}=0.041)$, while CD4+CD25hi Treg cells were higher in grade III compared to grade II patients in the after-surgery group $(\mathrm{P}=0.011)$ (Data not shown)

\section{Discussion: -}

In Egypt, breast cancer ranked the first, constituting $17.50 \%$ of total malignancies in females (Meloni et al., 2006).

Although T cells represent the most important immunological response in tumor growth, they become suppressive $\mathrm{CD}^{+}$and $\mathrm{CD}^{+}$Treg cells after chronic stimulation and interactions with tumor cells, thus promoting rather than inhibiting cancer development and progression (Mokhtar et al., 2007).

In this study, CD4+ lymphocytes were predominant in peripheral blood of de novo breast cancer patients and healthy controls groups compared to the after-surgery group $(\mathrm{P}=0.04)$.

Mozaffari et al. (2007) reported the same predominance of absolute number of CD4+ lymphocytes although it was statistically non-significant. Leong et al. (2006) showed that CD4+ lymphocyte \% was the $2^{\text {nd }}$ predominant subset (after CD8+) in the tumor microenvironment. Different sample analyses and different sample sizes may be the contributing factors for this discrepancy.

Tumor cells commonly participate in the generation of Treg cells, which provides an explanation for the observation that elevated numbers of Treg cells have been found in many types of cancer. It appears that TGF- $\beta$, secreted by the tumor itself or tumor-stimulated myeloid cells, plays a central role in tumor-mediated development of Treg cells by converting naïve T cells into Treg cells (Perez et al., 2007).

As regardsCD4+CD25+ and CD4+CD25hi, they were significantly higher in the de novo and the after-surgery cancer patients compared to the healthy controls and the benign patients' group.

Our result is consistent withWang et al. (2011) who foundthe same result in their study on peripheral blood of de novo breast cancer patients.

In our study, CD4+CD25hi subset was higher in the after-surgery patients compared to the de novo patients $(\mathrm{P}=0.04)$ and this was in accordance with the finding of Mozaffari et al (2007).

CD8+CD25+Treg cells share phenotypic and functional features with CD4+CD25+ Treg cells (Cosmi et al., 2006).We detected that the benign patients group had the highest percentage of CD $8+C D 25+\%$ Treg cells subset, followed by the after-surgery group. The de novo breast cancer patients and healthy controls group were almost the same, the differences were non-significant. .Mozaffari et al. (2007) reported a significant increase in CD8+CD25hi Treg cells in breast cancer patients after receiving adjuvant therapy compared to the de novo patients. Consistently, Shao et al. (2017) reported that the proportion of regulatory T cells (Treg) after chemotherapy in the disease control patients decreased significantly compared with that of the progressive patients and this difference affected 
significantly the overall survival. Pinho et al (2016) found that breast cancer patients have higher percentage of effector CD8+ T cells compared to healthy donors.

T-reg cells can offer a new insight into improving cancer therapies. Combined chemotherapeutic and immunomodulatory agents that showed their effect on T-reg can lead to marked suppression of tumor growth and prolongation of survival time (Xia et al., 2017 and Hekim et al., 2017).

A significant positive correlation was detected between the CD4+CD25+\% and the CD4+CD25hi \% in the de novo breast cancerpatients group $(\mathrm{P}<0.0001, \mathrm{r}=0.673)$ and in the benign group $(\mathrm{P}=0.002, \mathrm{r}=0.79)$, while there was a significant negative correlation between the $\mathrm{CD} 4+\mathrm{CD} 25+\%$ and $\mathrm{CD} 8+\mathrm{CD} 25+\%$ in the after-surgery patients group $(\mathrm{P}=0.018, \mathrm{r}=-0.583)$.

In agreement with our results, Zhu et al. (2015) and Leong et al. (2006) have demonstrated an insignificant negative correlation between the CD4+CD25+ cells and CD8+CD28+CD25+ obtained from TILs of breast cancer patients. They also found a significant positive correlation between CD4+CD25+ and CD8+CD28- subsets. In that study, CD8+CD28+CD25+ were defined as effector T cells and CD8+CD28- subset as Treg cells.

In our study, the observed negative relationship may be explained by the finding that not all CD8 + CD25+ population are Treg cells (Bisikirska et al., 2005).

CorrelatingCD4+CD25+ \% and CD $8+\mathrm{CD} 25+\%$ with some of the prognostic factors of breast cancer revealed a significant negative correlation between the CD4+CD25+\% and the age in the de novo and after surgery groups. However, a significant positive correlation was found between CD8+CD25+\% and age in the after-surgery group.

Similarly, Chui et al. (2004) reported that CD4+ Treg cells were higher in the blood of breast cancer patients $<65$ years in age. Tsaknaridis et al. (2003) also demonstrated that the suppressive activity of human CD4+CD25+ T cells declines with age in his study done on normal subjects. In contrast, Leong et al. (2006) found a significant positive correlation with age (> 50 years old).

This diversity of results may be due to differences in sample size or ethnic diversity.

Regarding tumor markers, a significant positive correlation was detected in the benign patients between CD4+CD25+\% and CEA ( $\mathrm{P}=0.005, \mathrm{r}=0.722)$, while CA15.3 didn't show any significant results. In contrast, AboEleinen et al. (2008) reported a significant positive correlation between $\mathrm{CD} 4+\mathrm{CD} 25+\%$ in the peripheral blood of 30 female breast cancer patients and CA15.3 $(\mathrm{P}=0.880, \mathrm{r}=0.001)$. This may be explained by the different stages of breast cancer patients enrolled in both studies.

CD4+CD25hi \% was significantly higher in the non-metastatic group compared to the metastatic group in de novo patients $(\mathrm{P}=0.041)$. Many studies have demonstrated that a higher Treg cells number within the tumor microenvironment or in peripheral blood would imply a worse prognosis and reduced survival (Wilke et al., 2010).

Significant higher percentage of CD4+CD25hi in the after-surgery group was detected in grade III compared to grade II $(\mathrm{P}=0.011)$. This was inconsistent with Leong et al. (2006).

We didn't find any significant relationship between CD4+CD25+ \% or CD4+CD25hi \% and the tumor stage, ER, PR or Her2neu status in both the de novo and the after-surgery patients groups. Our results are consistent with Song et al (2015) but different from Perez et al. (2007). Also, Mahmoud et al. (2011) and Bates et al. (2006) found significant correlations between Treg cells infiltration and ER negativity in breast cancer patients. Liu et al (2014) found that $\mathrm{CD} 4+\mathrm{CD} 25+\mathrm{FOXP} 3+$ regulatory TILs are a poor prognostic indicator in ER+ breast cancer, but a favorable prognostic factor in the HER2+/ER-ve subtype. Leong et al. (2006) found a significant positive correlation between CD4+CD25- T subset of TILs in breast cancer patients and ER. Estrogen has been reported to play a role in regulating the activation of human T cells particularly CD4+ and CD8+ T cells. The importance of ER- $\alpha$ in regulating the immune system is further supported by an in vivo murine model, where a high frequency of immature double CD4+CD8+ thymocytes was found in ER-anegative mice as compared to the ER- $\alpha$ positive mice (Erlandsson et al., 2001). 
This discrepancy between results may be attributed to the predominance of ER positivity in our studied population, different ethnic groups or menopausal status of the studied population.

In conclusion, some Treg cells as CD4+CD25+ cells are predominant in breast cancer patients, and show negative correlation with age and with CD8+CD25+ lymphocytes, which are predominant in the benign patients and after surgery patients.

Treg cells may play a role in modulation of effector $\mathrm{T}$ cell responses against breast tumors. Some Treg cells such as $\mathrm{CD} 4+\mathrm{CD} 25+$ cells maybe increased in cases of malignancy, while others, as CD8+CD25+ lymphocytes seem to play a protective role against malignancy. Further studies and larger sample sizes are needed to clarify the diagnostic and prognostic role of Treg cells in breast cancer progression. Treg can act as an immune-modulator in the therapeutic treatment of breast cancer patients weather alone or in combination with therapeutic vaccines and cytokines.

a)

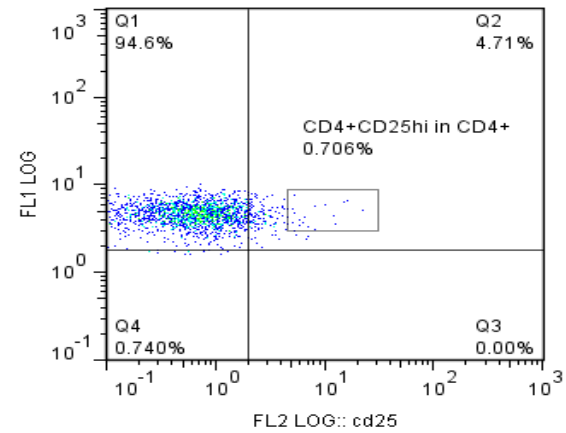

b)

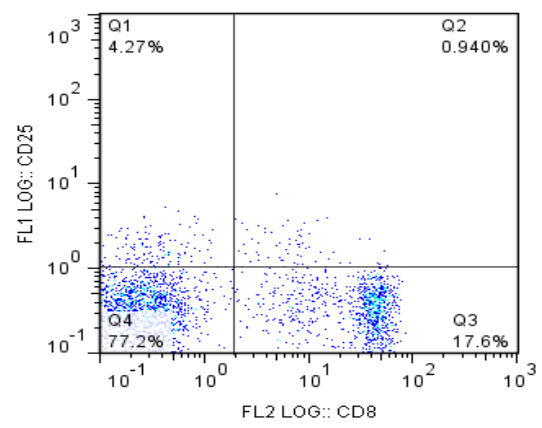

(Fig 1) a):- Positive expression of CD4+CD25+ and CD4+CD25hi subsets gated from CD4+ lymphocytes in a de novo patient. b) $\mathrm{CD} 8+\mathrm{CD} 25+$ subsets histogram from $\mathrm{CD} 3+$ lymphocytes gate in an after-surgery patient.

Table (1.a):- Clinical data of the de novo, after surgery and benign patients.

\begin{tabular}{|c|c|c|c|c|c|c|c|c|c|}
\hline & & \multicolumn{2}{|c|}{ De novo patients } & \multicolumn{2}{|c|}{$\begin{array}{l}\text { After-surgery } \\
\text { patients }\end{array}$} & \multicolumn{2}{|c|}{$\begin{array}{l}\text { Benign } \\
\text { patients }\end{array}$} & \multicolumn{2}{|c|}{ Total } \\
\hline & & $\begin{array}{l}\mathbf{n}= \\
\mathbf{3 0}\end{array}$ & $\begin{array}{l}\text { Percentage } \\
\%\end{array}$ & $\begin{array}{l}n= \\
17\end{array}$ & $\begin{array}{l}\text { Percentage } \\
\%\end{array}$ & $\begin{array}{l}n= \\
13\end{array}$ & $\begin{array}{l}\text { Percentage } \\
\%\end{array}$ & $\begin{array}{l}n= \\
60\end{array}$ & $\begin{array}{l}\text { Percentage } \\
\%\end{array}$ \\
\hline \multirow[t]{2}{*}{ Age } & $<50$ years & 14 & 47 & 7 & 41 & 7 & 54 & 28 & 47 \\
\hline & $\geq 50$ years & 16 & 53 & 10 & 59 & 6 & 46 & 32 & 53 \\
\hline \multirow{2}{*}{$\begin{array}{l}\text { Family } \\
\text { history }\end{array}$} & Positive & 4 & 13 & 0 & 0 & 0 & 0 & 4 & 7 \\
\hline & Negative & 26 & 87 & 17 & 100 & 13 & 100 & 56 & 93 \\
\hline \multirow{2}{*}{$\begin{array}{l}\text { Marital } \\
\text { status }\end{array}$} & Married & 29 & 97 & 17 & 100 & 9 & 69 & 55 & 92 \\
\hline & Single & 1 & 3 & 0 & 0 & 4 & 31 & 5 & 8 \\
\hline \multirow[t]{2}{*}{$\begin{array}{l}\text { Menarche } \\
\text { status }\end{array}$} & $\begin{array}{l}\text { Pre- } \\
\text { menopause }\end{array}$ & 12 & 40 & 7 & 41 & 9 & 69 & 28 & 47 \\
\hline & $\begin{array}{l}\text { Post- } \\
\text { menopause }\end{array}$ & 18 & 60 & 10 & 59 & 4 & 31 & 32 & 53 \\
\hline
\end{tabular}

n: number of patients. 
Table (1.b):- Clinical and pathological data of the de novo and after surgery patients.

\begin{tabular}{|c|c|c|c|c|c|c|c|}
\hline & & \multicolumn{2}{|c|}{ De novo patients } & \multicolumn{2}{|c|}{$\begin{array}{ll}\text { After } & \text { surgery } \\
\text { patients } & \end{array}$} & \multicolumn{2}{|l|}{ Total } \\
\hline & & $\mathbf{n}=\mathbf{3 0}$ & Percentage & $\mathbf{n}=\mathbf{1 7}$ & Percentage & $\mathrm{n}=47$ & Percentage \\
\hline \multirow[t]{2}{*}{ Tumor size } & Tumor size $\leq 5 \mathrm{~cm}$ & 24 & 80 & 12 & 71 & 36 & 77 \\
\hline & Tumor size $>5 \mathrm{~cm}$ & 6 & 20 & 5 & 29 & 11 & 23 \\
\hline \multirow{2}{*}{$\begin{array}{l}\text { Lymph } \\
\text { status }\end{array}$} & Positive & 29 & 97 & 13 & 76 & 42 & 89 \\
\hline & Negative & 1 & 3 & 4 & 24 & 5 & 11 \\
\hline \multirow{2}{*}{$\begin{array}{l}\text { Distant } \\
\text { metastasis }\end{array}$} & Present & 14 & 47 & 5 & 29 & 19 & 40 \\
\hline & Absent & 16 & 53 & 12 & 71 & 28 & 60 \\
\hline \multirow[t]{4}{*}{ Tumor stage * } & Stage I & 1 & 3 & 0 & 0 & 1 & 2 \\
\hline & Stage II & 9 & 30 & 7 & 41 & 16 & 34 \\
\hline & Stage III & 5 & 17 & 4 & 24 & 9 & 19 \\
\hline & Stage IV & 15 & 50 & 6 & 35 & 21 & 45 \\
\hline \multirow[t]{2}{*}{ Grade } & II & 26 & 87 & 12 & 71 & 38 & 81 \\
\hline & III & 4 & 13 & 5 & 29 & 9 & 19 \\
\hline \multirow[t]{2}{*}{ Tumor focality } & Unifocal & 26 & 87 & 14 & 82 & 40 & 85 \\
\hline & Multifocal & 4 & 13 & 3 & 18 & 7 & 15 \\
\hline \multirow[t]{2}{*}{ ER } & Positive & 24 & 80 & 10 & 59 & 34 & 72 \\
\hline & Negative & 6 & 20 & 7 & 41 & 13 & 28 \\
\hline \multirow[t]{2}{*}{ PR } & Positive & 11 & 37 & 14 & 82 & 25 & 53 \\
\hline & Negative & 19 & 63 & 3 & 18 & 22 & 47 \\
\hline \multirow[t]{2}{*}{ HER2/neu } & Positive & 4 & 13 & 7 & 41 & 11 & 23 \\
\hline & Negative & 26 & 87 & 10 & 59 & 36 & 77 \\
\hline
\end{tabular}

* Stage according to TNM classification for breast cancer (AJCC).

n: number of patients, Grade: Pathological grade, ER: Estrogen receptor, PR: Progesterone receptor, HER2/neu: Human Epidermal growth factor Receptor 2.

Table (2):- Comparison of different lymphocyte populations in the different studied groups (de novo, after surgery, benign patients and healthy controls) using Krusal-Wallis test:

\begin{tabular}{|c|c|c|c|c|c|}
\hline & $\begin{array}{l}\text { Healthy } \\
\text { controls }\end{array}$ & $\begin{array}{ll}\text { De } & \text { novo } \\
\text { patients } & \\
\end{array}$ & $\begin{array}{l}\text { After surgery } \\
\text { patients }\end{array}$ & $\begin{array}{l}\text { Benign } \\
\text { patients }\end{array}$ & P-value \\
\hline & Median \& & Median \& & Median \& & Median \& & \\
\hline & IR (Q1 - Q3) & IR (Q1 - Q3) & IR (Q1 - Q3) & IR (Q1 - Q3) & \\
\hline \multirow[t]{2}{*}{ Total lymphocytes \% } & 84.7 & 88.65 & 89.2 & 90 & \multirow[t]{2}{*}{0.15} \\
\hline & $(82-87.8)$ & $(86-92.3)$ & $(81-91)$ & $(88-91)$ & \\
\hline \multirow[t]{2}{*}{ CD3+ lymphocytes \% } & 76.95 & 69.8 & 67.15 & 77.8 & \multirow[t]{2}{*}{0.27} \\
\hline & $(67.6-88.1)$ & $(58.2-85.1)$ & $(47.8-82.6)$ & $(64.6-85.4)$ & \\
\hline \multirow{2}{*}{ CD4+ lymphocytes \% } & $65.25 \mathbf{a}$ & $65.6 \mathrm{~b}$ & $55.7 \mathbf{a}, \mathbf{b}$ & 52.7 & \multirow[t]{2}{*}{0.04} \\
\hline & $(61.9-72.4)$ & $(57.5-75)$ & $(46.5-67)$ & $(51-71.9)$ & \\
\hline \multirow[t]{2}{*}{ CD8+ lymphocytes \% } & 17 & 16.5 & 19.7 & 16.6 & \multirow[t]{2}{*}{0.57} \\
\hline & $(12.1-20.5)$ & $(13.5-20.9)$ & $(12.7-33.7)$ & $(9.4-20.9)$ & \\
\hline \multirow[t]{2}{*}{ CD4+/CD8+ ratio } & 3.57 & 3.79 & 2.83 & 3.46 & \multirow[t]{2}{*}{0.13} \\
\hline & $(3.4-5.9)$ & $(3.3-4.6)$ & $(1.45-4.1)$ & $(3.2-5.1)$ & \\
\hline \multirow[t]{2}{*}{$\mathrm{CD} 4+\mathrm{CD25}+\%$} & $2.1 \mathbf{c , d}$ & $3.78 \mathbf{c}$ & $4.46 \mathbf{d}, \mathbf{e}$ & $3.11 \mathrm{e}$ & \multirow[t]{2}{*}{$<0.0001$} \\
\hline & $(1.7-2.5)$ & $(3.1-4.6)$ & $(3.95-4.9)$ & $(1.9-3.6)$ & \\
\hline \multirow[t]{2}{*}{ CD4+CD25hi \% } & $0.27 \mathbf{f}, \mathrm{g}$ & $0.7 \mathbf{f}$ & $0.8 \mathrm{~g}$ & 0.43 & \multirow[t]{2}{*}{$<0.0001$} \\
\hline & $(0.15-0.35)$ & $(0.47-0.85)$ & $(0.7-1.1)$ & $(0.22-0.57)$ & \\
\hline \multirow[t]{2}{*}{$\mathrm{CD8}+\mathrm{CD25}+\%$} & 0.81 & 0.89 & 0.94 & 0.96 & \multirow[t]{2}{*}{0.24} \\
\hline & $(0.54-0.85)$ & $(0.5-1.12)$ & $(0.7-1.2)$ & $(0.56-1.7)$ & \\
\hline
\end{tabular}

IR: Interquartile range

* Groups with the same letter show statistically significant difference 
Table (3):- Correlation analysis between the different Treg cells subsets \% in the different patients' groups

\begin{tabular}{|c|c|c|c|c|}
\hline & & & CD4+CD25hi \% & CD8+CD25+ \% \\
\hline & \multirow{2}{*}{$\mathrm{CD} 4+\mathrm{CD25}+\%$} & $\mathbf{r}$ & 0.673 & -0.159 \\
\hline \multirow{3}{*}{$\begin{array}{ll}\text { De } & \text { novo } \\
\text { patients } & \\
\end{array}$} & & $\mathbf{P}$ & $<0.0001 * *$ & 0.438 \\
\hline & \multirow[t]{2}{*}{ CD4+CD25hi \% } & $\mathbf{r}$ & & -0.229 \\
\hline & & $\mathbf{P}$ & & 0.261 \\
\hline & \multirow[t]{2}{*}{$\mathrm{CD} 4+\mathrm{CD25}+\%$} & $\mathbf{r}$ & 0.33 & -0.583 \\
\hline \multirow{3}{*}{$\begin{array}{l}\text { After surgery } \\
\text { patients }\end{array}$} & & $\mathbf{P}$ & 0.212 & $0.018^{*}$ \\
\hline & \multirow[t]{2}{*}{ CD4+CD25hi \% } & $\mathbf{r}$ & & -0.007 \\
\hline & & $\mathbf{P}$ & & 0.978 \\
\hline & \multirow[t]{2}{*}{$\mathrm{CD} 4+\mathrm{CD25}+\%$} & $\mathbf{r}$ & 0.79 & -0.116 \\
\hline \multirow[t]{3}{*}{ Benign patients } & & $\mathbf{P}$ & $0.002 * *$ & 0.721 \\
\hline & \multirow[t]{2}{*}{ CD4+CD25hi \% } & $\mathbf{r}$ & & 0.068 \\
\hline & & $\mathbf{P}$ & & 0.842 \\
\hline \multicolumn{5}{|l|}{ * Significant. } \\
\hline \multicolumn{5}{|c|}{ **Highly significant } \\
\hline
\end{tabular}

Table (4):- Correlation analysis between different Treg cells subsets \% with the clinical, histopathological and laboratory data in the different patients' groups (de novo, after surgery and benign patients):

\begin{tabular}{|c|c|c|c|c|c|}
\hline & & & CD4+CD25+ \% & CD4+CD25hi \% & CD8+CD25+ \% \\
\hline Age & De novo & $\mathrm{r}$ & -0.388 & -0.214 & 0.119 \\
\hline & & $\mathrm{P}$ & 0.038* & 0.266 & 0.554 \\
\hline & After surgery & $\mathrm{r}$ & -0.612 & 0.267 & 0.487 \\
\hline & & $\mathrm{P}$ & 0.012* & 0.301 & 0.048* \\
\hline & Benign & $\mathrm{r}$ & 0.29 & 0.035 & 0.248 \\
\hline & & $\mathrm{P}$ & 0.336 & 0.914 & 0.437 \\
\hline Tumor size & De novo & $\mathrm{r}$ & -0.075 & -0.201 & 0.21 \\
\hline & & $\mathrm{P}$ & 0.701 & 0.296 & 0.294 \\
\hline & After surgery & $\mathrm{r}$ & 0.025 & -0.051 & 0.467 \\
\hline & & $\mathrm{P}$ & 0.926 & 0.846 & 0.058 \\
\hline CEA & De novo & $\mathrm{r}$ & -0.279 & 0.034 & -0.131 \\
\hline & & $\mathrm{P}$ & 0.143 & 0.859 & 0.515 \\
\hline & After surgery & $\mathrm{r}$ & 0.148 & 0.221 & 0.108 \\
\hline & & $\mathrm{P}$ & 0.584 & 0.393 & 0.679 \\
\hline & Benign & $\mathrm{r}$ & 0.722 & 0.493 & 0.155 \\
\hline & & $\mathrm{P}$ & $0.005 * *$ & 0.103 & 0.631 \\
\hline CA 15-3 & De novo & $\mathrm{r}$ & -0.025 & -0.065 & -0.002 \\
\hline & & $\bar{P}$ & 0.896 & 0.737 & 0.993 \\
\hline & After surgery & $\mathrm{r}$ & -0.091 & -0.422 & 0.174 \\
\hline & & $\mathrm{P}$ & 0.737 & 0.092 & 0.504 \\
\hline & Benign & $\mathrm{r}$ & 0.544 & 0.371 & -0.315 \\
\hline & & $\mathrm{P}$ & 0.055 & 0.236 & 0.318 \\
\hline
\end{tabular}

* Significant. ** Highly significant.

\section{Acknowledgment: -}

This study was supported technically and partly funded by the hematology unit, Clinical Pathology department, National Cancer Institute, Cairo University, Egypt. 


\section{References: -}

1. Abo-Elenein A, Elgohary SE, Hashish A and El-Halaby E, Significance of immunoregulatory $\mathrm{T}$ cells in different stages of breast cancer patients. Egypt J Immunol., 2008; 15(2): 145-52.

2. Bates GJ, Fox SB, Han C, Leek RD, Garcia JF, Harris AL and Banham AH, Quantification of Regulatory T Cells Enables the Identification of High-Risk Breast Cancer Patients and Those at Risk of Late Relapse. J ClinOncol., 2006; 24(34): 5373-80.

3. Baumgartner JM and McCarter MD, Suppressing the suppressor: Role of immunosuppressive regulatory T cells in cancer surgery. Surgical Research Review 2009; 145 : 345-50.

4. Bisikirska B, Colgan J, Luban J, Bluestone JA and Herold KC, TCR stimulation with modified anti-CD3 mAb expands CD8+ T cell population and induces CD8+CD25+ Tregs. J Clin Invest. 2005;115: 2904-13.

5. Chui SY, Morse MA, Doldo T, Osada T, Clay TM, Lyerly HK, Khan S, Gattis A and Hobeika AC, Regulatory and effector T cell subsets and dendritic cells in breast cancer., Journal of Clinical Oncology 2004; 22 (14S): 9697.

6. Cosmi L, Liotta F, Lazzeri E, Francalanci M, Angeli R, Mazzinghi B, Santarlasci V, Manetti R, Vanini V, Romagnani P, Maggi E, Romagnani S and Annunziato F, Human CD8+CD25+ thymocytes share phenotypic and functional features with CD4+ CD25+ regulatory thymocytes. Blood 2003; 102:4107-14.

7. Erlandsson MC, Ohlsson C, Gustafsson JA, Carlsten H, Role of oestrogen receptors alpha and beta in immune organ development and in oestrogen-mediated effects on thymus. Immunology, 2001: 103:17-25.

8. Hekim C1, Ilander M1, Yan J2, Michaud E2, Smykla R2, Vähä-Koskela M3, Savola P1, Tähtinen S3, Saikko L4, Hemminki A3, Kovanen PE4, Porkka K1, Lee FY2, Mustjoki S5. Dasatinib Changes Immune Cell Profiles Concomitant with Reduced Tumor Growth in Several Murine Solid Tumor Models.Cancer Immunol Res. 2017 Feb;5(2):157-169.

9. Jemal A, Bray F, Center MM, Ferlay J, Ward E, Forman D, Global Cancer Statistics CA. CANCER J CLIN.2011: 61:69-90.

10. Leong PP, Mohammad R, Ibrahim N, Ithnin H, Abdullah M, Davis WC,Seow HF, Phenotyping of lymphocytes expressing regulatory and effector markers in infiltrating ductal carcinoma of the breast. Immunology Letters.2006: 102: 229-236.

11. Liu S, Foulkes WD, Leung S, Gao D, Lau S, Kos Z, Nielsen TO, Prognostic significance of FOXP3+ tumorinfiltrating lymphocytes in breast cancer depends on estrogen receptor and human epidermal growth factor receptor-2 expression status and concurrent cytotoxic T-cell infiltration. Breast Cancer Res. 2014 Sep 6;16(5):43.

12. Maggi E, Cosmi L, Liotta F, Romagnani P, Romagnani S, Annunziato F, Thymicregulatory $T$ cells. Autoimmun Rev., (2005):4: 579-86.

13. Mahmoud SMA, Paish EC, Powe DG, Macmillan RD, Lee AHS, Ellis IO, Green AR, An evaluation of the clinical significance of FOXP3+ infiltrating cells in human breast cancer. Breast Cancer Research and Treatment. 2011: May; 127(1): 99-108.

14. Meloni F, Morosini M, Solari N, Passadore I, Nascimbene C, Novo M, Ferrari M, Cosentino M, Marino F, Pozzi E, Fietta AM,Foxp3 expressing CD4+ CD25+ and CD8+CD28- T regulatory cells in the peripheral blood of patients with lung cancer and pleural mesothelioma. Hum Immunol.2006: 67:1-12.

15. Mokhtar N, Gouda I, Adel I, Breast cancer. In Mokhtar, N., Gouda, I., Adel, I. (eds.): Cancer pathology registry, 2003-2004 and time trend analysis 2007: Cairo, NCI, El Sheraa Press. Available online: http://www.nci.cu.edu.eg/ (accessed 26/12/2011).

16. Mozaffari F, Lindemalm C, Choudhury A, Granstam-Bjo“rneklett H, Helander H, Lekander M, Mikaelsson E, Nilsson B, Ojutkangas ML, Osterborg A, Bergkvist L, Mellstedt H,NK-cell and T-cell functions in patients with breast cancer: effects of surgery and adjuvant chemo- and radiotherapy. British Journal of Cancer.2007: 97:105-11.

17. Perez SA, Karamouzis MV, Skarlos DV et al., CD4+CD25+ regulatory T-cell frequency in HER-2/neu (HER)-positive and HER-negative advanced-stage breast cancer patients. 2007: Clin. Cancer Res., 13: 27142721.

18. Pinho MB and Barbuto JAM, Systemic alterations in T cell subpopulations of breast cancer patients. Cancer Immunol Res. 2016 January 4 (1 suppl); abstract B096.

19. Shao B1, Li HP1, DI LJ1, Song GH1, Jiang HF1, Liang X1, Wang CY1, Yan Y1, Lin XL1, Wang LN1, Wan FL1, Yuan YH1, You MN1.Predictive and prognostic value of monitoring lymphocyte subsets in peripheral blood before and after chemotherapy in patients with metastatic breast cancer.ImmunopharmacolImmunotoxicol. 2017 Feb;39(1):37-44. 
20. Song Q, Ren J, Zhou X, Wang X, Song G, Di L, Yu J, Hobeika A, Morse MA, Yuan Y, Yang H, Lyerly HK, The prognostic value of peripheral CD4+CD25+ T lymphocytes among early stage and triple negative breast cancer patients receiving dendritic cells-cytokine induced killer cells infusion. Oncotarget. 2015 Dec 1; 6(38): $41350-41359$.

21. Tsaknaridis L, Spencer L, Culbertson N, Hicks K, LaTocha D, Chou YK, Whitham RH, Bakke A, Jones RE, Offner H, Bourdette DN, Vandenbark AA,Functional assay for human CD4+CD25+ Treg cells reveals an age-dependent loss of suppressive activity. J Neurosci Res, 2003:15; 74(2):296-308

22. Wang Z, Yang B, Liu H, Hu Y, Yang J, Wu L, Zhou Z, Jiao S, Regulatory T cells increase in breast cancer and in stage IV breast cancer. Cancer Immunology Immunotherapy.2011: 24 November.

23. Wilke CM. Wu K, Zhao E, Wang G, Zou W, Prognostic significance of regulatory $\mathrm{T}$ cells in tumor International Journal of Cancer. 2010:127(4): 748-58.

24. Xia Q1, Geng F1, Zhang FF1, Liu CL1, Xu P1, Lu ZZ1, Xie Y1, Sun B1, Wu H1, Yu B1, Kong W1, Yu XH1, Zhang HH1.Cyclophosphamide enhances anti-tumor effects of a fibroblast activation protein $\alpha$-based DNA vaccine in tumor-bearing mice with murine breast carcinoma.ImmunopharmacolImmunotoxicol. 2017 Feb;39(1):37-44.

25. Zhang L, Zhao Y, The regulation of Foxp3 expression in regulatory CD4 (+) CD25 (+) T cells: multiple pathways on the road. J Cell Physiol., 2007: 211(3):590-7.

26. Zhu S1, Lin J1, Qiao G1, Xu Y2, Zou H3, Differential regulation and function of tumor-infiltrating T cells in different stages of breast cancer patients. Tumour Biol. 2015 Sep;36(10):7907-13. 